\title{
Pain in onco-hematologic patients and its association with analgesia
}

\author{
Caracterização da dor em pacientes onco-hematológicos e sua associação com a analgesia
}

Isadora Marques Barbosa', Diane Sousa Sales², Lidiane Marha de Souza Oliveira ${ }^{3}$, Damiana Vieira Sampaio ${ }^{4}$, Anny Giselly Milhome ${ }^{5}$

DOI 10.5935/1806-0013.20160066

\section{ABSTRACT}

BACKGROUND AND OBJECTIVES: It is understood that in light of the increasing number of cancer diagnoses, one should intensify the quality of assistance offered to those patients, aiming at improving quality of life and minimizing suffering of patients and their relatives. Nursing assistance should be enhanced and focused on cancer patients' pain evaluation, to help pain characterization and, as a consequence, to improve multiprofessional assistance. This study aimed at characterizing onco-hematologic patients' pain and at associating it to offered analgesia.

METHODS: This is a descriptive, prospective and longitudinal study developed with 20 patients with onco-hematologic disease admitted to the hematology unit, Hospital Universitário Walter Cantídeo. Visual analog scale and pain numerical scale were applied, in addition to multidimensional pain evaluation scale and McGil questionnaire.

RESULTS: Primary cause of pain was intestinal infection. Acute pain lasting the whole day has prevailed. According to multidimensional pain evaluation scale, most commonly reported acute descriptor was deep, and of chronic persistent. Most commonly mentioned word of McGill questionnaire was unbearable, being the evaluative category the most commonly used. When evaluating analgesia, it was noted that 12 out of 20 medical prescriptions were incompatible with World Health Organization recommendations.

CONCLUSION: Scales are extremely important to measure and characterize pain. The nursing team should be at the front for its implementation and use in hospital units, especially in cancer units due to the high incidence of this symptom.

Keywords: Analgesia, Nursing, Oncology, Pain, Scales.

1. Universidade Federal do Ceará, Hospital Universitário Walter Cantídio, Departamento de Enfermagem, Fortaleza, CE, Brasil.

2. Universidade Estadual do Ceará, Departamento de Enfermagem, Fortaleza, CE, Brasil. 3. Universidade Aberta do Sistema Único de Saúde, Fortaleza, CE, Brasil.

4. Faculdade Metropolitana da Grande Fortaleza, Departamento de Enfermagem, Fortaleza, CE, Brasil.

5. Universidade Federal do Ceará, Departamento de Enfermagem, Fortaleza, CE, Brasil.

Submitted in March 22, 2016.

Accepted for publication in August 08, 2016.

Conflict of interests: none - Sponsoring sources: none.

Correspondence to:

Rua Padre Justino, n. 202 - Praia de Iracema

60060-400 Fortaleza, CE, Brasil.

E-mail: isadoramarx@gmail.com

() Sociedade Brasileira para o Estudo da Dor

\section{RESUMO}

JUSTIFICATIVA E OBJETIVOS: Entende-se que diante da crescente incidência no diagnóstico de câncer, deve-se intensificar a qualidade da assistência oferecida a esses pacientes, com o intuito de melhorar a qualidade de vida e amenizar o sofrimento dos pacientes e dos familiares. A assistência de enfermagem deve ser aprimorada e focada na avaliação da dor do paciente oncológico, para facilitar a caracterização da dor e, consequentemente, melhorar o tratamento multiprofissional. O objetivo deste estudo foi caracterizar a dor dos pacientes onco-hematológicos e associar com a analgesia ofertada.

MÉTODOS: Estudo descritivo, prospectivo, longitudinal, desenvolvido com 20 pacientes que apresentaram diagnóstico de doença onco-hematológica e que estivesse internado na unidade de hematologia do Hospital Universitário Walter Cantídeo. Foram aplicadas as escalas analógicas visual e numérica da dor, multidimensional de avaliação de dor e o questionário de McGill.

RESULTADOS: A principal causa de dor foi por infecção intestinal. Prevaleceu a dor aguda e que durava o dia todo. Pela escala multidimensional de avaliaçáo de dor o descritor agudo mais relatado foi profundo e do crônico persistente. A palavra mais citada no McGill foi insuportável, com a categoria avaliativa sendo a mais utilizada. $\mathrm{Na}$ avaliação da analgesia, percebeuse que 13 das 20 prescriçóes médicas estavam incompatíveis com as recomendaçóes da Organizaçáo Mundial da Saúde.

CONCLUSÁO: As escalas são de extrema importância na mensuração e caracterização da dor. A enfermagem deve estar à frente na sua implantação e utilização nas unidades hospitalares, de maneira especial nas oncológicas pela alta incidência desse sintoma. Descritores: Analgesia, Dor, Enfermagem, Escalas, Oncologia.

\section{INTRODUCTION}

Pain is a sensory, emotional and undesirable experience associated to real or potential tissue injury or described in terms of such injury. It is subjective because it is what people say they feel, and exists whenever people say so. However, the impossibility of verbally communicating does not deny the possibility of someone having pain and needing relief ${ }^{1}$.

A major cause of incapacity and distress for progressing cancer patients is pain, being that approximately $80 \%$ of these cases shall experience some type of pain. In approximately $20 \%$ of cancer patients pain might be related to treatment, be it surgical, chemotherapeutic or radiotherapeutic, but it may also be directly triggered by the tumor, or by reasons 
unrelated to cancer, such as metabolic, infectious, carential or degenerative changes ${ }^{2}$.

Cancer pain has acute and chronic characteristics. As acute pain, cancer pain is directly related to tissue injury. Chronic pain is also associated to repetitive nociceptive stimulations which induce several central nervous system (CNS) changes ${ }^{3}$.

Painful experience and its interpretation are result of the interrelation of sensory, affective, cognitive, neurovegetative, neuroendocrine and neuroimmunologic components which is expressed due to nociceptive system stimulation or disorder ${ }^{4}$.

So, all cancer patients should be evaluated by the nursing team for the presence and intensity of pain, due to their proximity with patients ${ }^{2}$. In the clinical practice, the lack of pain measurement tools may impair the quality of assistance, thus making difficult adequate diagnosis and therapeutic approach, in addition to mistakes caused by underevaluation ${ }^{5}$.

Currently there is the visual analog scale (VAS) or numeric scale (NVS), where patients mark the most approximate position of their pain intensity ${ }^{6}$. McGill questionnaire is also an internationally recognized standard tool and adapted for the Portuguese language ${ }^{7}$.

There are also other ways to evaluate and follow pain pattern, even to help analgesia. With this aim, the multidimensional pain evaluation scale was developed (EMADOR). EMADOR is made up of NVS, of acute (10) and chronic (10) pain descriptors and of pain location by patients ${ }^{3}$.

Nurses play critical role in acute and chronic pain evaluation, especially in cancer patients. In general, they are the first professionals to notice patients' pain, and should be the first to look for solution with the multiprofessional team. For the nursing team, pain evaluation and measurement are mandatory and useful in all stages of assistance and of knowledge production which, in addition to other objectives different from patients' management and monitoring, may determine adequate metrological characteristics for different types of pain ${ }^{8}$.

Due to the increasing incidence of cancer diagnoses, one should intensify the quality of assistance aiming at improving quality of life (QL) and minimizing patients and relatives' distress.

This study aimed at characterizing onco-hematologic patients' pain and at associating it to offered analgesia.

\section{METHODS}

This is a descriptive prospective study developed with 20 patients diagnosed with onco-hematologic disease admitted to the hematology unit of Hospital Universitário Walter Cantídio (HUWC), Universidade Federal do Ceará, from August to November 2013. Convenience sample was based on monthly average of 7 hospitalized patients, in a total of 28 patients during 4 months of data collection. From these, just 20 patients matched inclusion criteria.
Inclusion criteria were adult patients admitted to the hematology sector and with verbal pain report during the data collection period. Exclusion criteria were patients with inconclusive diagnosis of onco-hematologic disease; those who abandoned treatment during data collection or those transferred to other sector or other hospital; and those who could not have been followed up for at least four days by investigators.

Research tool was made up of three parts: 1) sample characterization with regard to identification, social factors, clinical aspects of the disease and presence or not of pain in the interview day; 2) pain was characterized by means of questions such as possible etiology, when pain had started, pain duration, worsening factors and whether there was interference with routine activities, in addition to the application of $\mathrm{NVS}^{6}$, EMADOR ${ }^{3}$ and McGill pain questionnaire'; 3) pain control: prescribed analgesics.

VNS was used to evaluate pain. Pain is considered mild when intensity varies from 1 to $3 ; 4$ to 7 is considered moderate intensity; and 8 to 10 severe pain 6 .

Patients were daily evaluated until hospital discharge, transfer or death, to observe whether applied scale scores or offered analgesia had changed, depending on availability in the unit and because continuous evaluation was recommended. Then, pain indices and offered analgesia were compared.

EMADOR is made up of pain NVS, of acute pain descriptors (10) and chronic pan descriptors (10) and of pain location by patients ${ }^{3}$.

McGill pain questionnaire is a tool with four categories, namely: sensory, with mechanical, thermal and spatial pain properties; affective, affective-psychogenic dimension of tension, fear and emotions; evaluative, expresses global pain evaluation; and miscellaneous, a mixture of several factors. These categories are divided in 20 sub-categories describing different pain qualities. Each word represents one descriptor and is scored from 1 to 6 in some sub-categories?.

Tool was applied in full in the first day of pain reported by patients, starting the follow up of the case. Subsequent evaluations were performed daily until hospital discharge, transfer or death, to see whether there had been changes in pain characteristics and control. In average, patients were followed for 8.45 days. During this period, pain characteristics were daily evaluated with the tool.

EMADOR was daily applied, being patients asked to choose a descriptor which would best define their pain at that moment, being confirmed by pain intensity according to NVS. Pain was classified as acute (less than six months) or chronic (more than six months) and as from this division descriptors were shown for patients to choose from. At the end, patients were divided in acute and chronic pain patients and more frequently chosen words were identified.

With regard to McGill questionnaire, patients were asked to choose words that best characterized their pain and they could choose none or just one word per subgroup. At the end, most frequently chosen words, number of descriptors and pain index were identified. 
All participants have signed the Free and Informed Consent Term (FICT), after being explained about the objective of the study, before data collection, according to Resolution $466 / 2012$.

\section{Statistical analysis}

After collection, data were tabulated in Excel spreadsheets and statistically analyzed by the statistical program SPSS, version 20.0. Absolute frequencies and means were calculated for descriptive variables. Results were presented in tables. The study was approved by the Research Ethics Committee, HUWC, under favorable opinion 216.276.

\section{RESULTS}

With regard to general characterization of 20 studied patients, 11 were females and 9 were males. Most prevalent age group was between 18 and 29 years, with $35 \%(n=7)$, followed by those aged 60 years or above, with $25 \%(n=5)$ and $20 \%$ in each interval from 30 to 49 years of age and $20 \%(n=4)$ from 50 to 59 years of age.

As to marital status, $45 \%(n=9)$ were married, followed by $40 \%(\mathrm{n}=8)$ single, $10 \%(\mathrm{n}=2)$ widowers and $5 \%(\mathrm{n}=1)$ divorced. As to number of children, $40 \%(n=8)$ had no children, $35 \%(n=7)$ two children and $25 \%(n=5)$ three or more children.

According to education level, 55\% $(\mathrm{n}=11)$ had finished high school, 35\% ( $\mathrm{n}=7)$ had finished elementary school, and literate and with complete college were $5 \%(n=1)$ each.

With regard to clinical disease aspects, type of onco-hematologic diagnosis and time from diagnosis were evaluated and the most prevalent diagnosis was acute myeloid leukemia (AML) with $30 \%$ of cases, followed by non-Hodgkin lymphoma (NHL) and multiple myeloma with 15\% each. As to time from diagnosis, patients had predominantly been diagnosed less than one year ago $(70 \%)$. All patients reported pain in the first data collection day, being this a criterion to establish pain profile.

To characterize pain, the following questions were asked: possible etiology, when pain started, its duration, which were worsening factors, and whether there was interference with routine activities, as shown in table 1 .

With regard to pain etiology, it was observed that intestinal infection (30\%) and mucositis (20\%) were the most frequently reported. Most patients reported having pain most part of the day $(70 \%)$. Worsening factors were especially food intake (40\%) and movement $(30 \%)$. Pain has prevented adequate walking (35\%) and food intake (30\%).

Pain intensity was evaluated with NVS. As from initial NVS, it was identified that $15 \%$ of patients had intensity between 1 and 3 (mild pain), 10\% between 4 and 7 (moderate pain) and $75 \%$ between 8 to 10 (severe pain). General mean pain intensity during follow up was 6.5.

EMADOR was daily applied, being patients asked to choose the descriptor best defining their pain at that moment. Table 2 shows most frequent descriptors mentioned during
Table 1. Pain characterization in onco-hematologic patients. Fortaleza - CE

\begin{tabular}{lccc}
\hline Pain etiology & \multicolumn{3}{c}{ Pain onset } \\
Causes & $\%(\mathrm{n})$ & Time & $\%(\mathrm{n})$ \\
\hline Intestinal infection & $30(6)$ & $>6$ months & $20(4)$ \\
Mucositis & $20(4)$ & $<6$ months & $80(16)$ \\
Pressure sore & $10(2)$ & & \\
Headache & $10(2)$ & Duration & $\%(\mathrm{n})$ \\
Hemorrhoid & $10(2)$ & Intermittent & $30(6)$ \\
Other causes & $20(4)$ & Whole day & $70(14)$ \\
\hline Worsening factors & & Interference with RA \\
& $\%(\mathrm{n})$ & Activities & $\%(\mathrm{n})$ \\
\hline Food intake & $40(8)$ & Walking & $35(7)$ \\
Movement & $30(6)$ & Food intake & $30(6)$ \\
Evacuation & $15(3)$ & Sleep/Rest & $20(4)$ \\
Noise & $10(2)$ & Elimination & $10(2)$ \\
Breathing & $5(1)$ & No change & $5(1)$ \\
\hline
\end{tabular}

$\mathrm{RA}=$ routine activities

patients' follow up.

There were more patients with acute pain, with $80 \%(n=16)$, than patients with chronic pain. For acute pain most frequent descriptor was deep (35.7\%). For chronic pain, most frequent descriptor was persistent (31.4\%). It was observed that for acute pain, only one descriptor has not been mentioned, annihilating. Among chronic pain descriptors, four were not mentioned: depressing, disastrous, harmful and fearful.

In McGill questionnaire, when patients were asked to choose words best defining their pain, most frequent were: jumping $(80 \%)$, troublesome $(75 \%)$, intense $(75 \%)$, miserable $(70 \%)$ and penetrating $(70 \%)$. Nineteen words were not mentioned by any patient, such as flickering, pulsing, beating, pounding, shooting, stabbing, gnawing, crushing, scalding, searing, tingling, itchy and aching, among others. From the 20 subgroups, only one had no word mentioned, being it the miscellaneous group, subgroup 19 with the words: cool, cold and freezing.

Table 2. Descriptors identified as from multidimensional pain evaluation scale. Fortaleza - CE

\begin{tabular}{lccc}
\hline Acute pain & \multicolumn{2}{c}{ Chronic pain } \\
Descriptors & $\%(\mathrm{n})$ & Descriptors & $\%(\mathrm{n})$ \\
\hline Deep & $35.7(45)$ & Persistent & $31.4(11)$ \\
Intense & $27.8(35)$ & Unbearable & $22.8(8)$ \\
Unbearable & $13.5(17)$ & Hurting & $20(7)$ \\
Desperate & $7.1(9)$ & Agonizing & $14.3(5)$ \\
Blinding & $5.5(7)$ & Uncomfortable & $8.6(3)$ \\
Monstrous & $4.8(6)$ & Cruel & $2.9(1)$ \\
Fulminant & $4(5)$ & & \\
Terrible & $0.8(1)$ & & \\
Tremendous & $0.8(1)$ & & \\
\hline
\end{tabular}


Table 3. Maximum number of descriptors and maximum pain index of the onco-hematologic population according to McGill questionnaire. Fortaleza-CE

\begin{tabular}{|c|c|c|c|c|c|}
\hline Categories & Maximum sub-categories & $\%$ & Categories & Maximum pain index & $\%$ \\
\hline Sensory $(n=10)$ & 5 & 35 & Sensory $(n=42)$ & 13 & 15 \\
\hline Affective $(n=5)$ & 3 & 45 & Affective $(n=14)$ & 5 & 25 \\
\hline Evaluative $(n=1)$ & 1 & 100 & Evaluative $(n=5)$ & 5 & 40 \\
\hline Miscellaneous $(n=4)$ & 3 & 60 & Miscellaneous $(n=17)$ & 10 & 15 \\
\hline Total $(n=20)$ & 12 & 35 & Total $(n=78)$ & 34 & 15 \\
\hline
\end{tabular}

As from McGill questionnaire, it is possible to identify the maximum number of selected sub-categories, by category or total, and pain index, by category or total, as shown in table 3 .

In the evaluation by selected descriptor for each category it was identified that in sensory category, most frequent were: jumping (11.5\%), tugging (8.6\%) and throbbing (6.5\%). In the affective category, most common descriptors were: exhausting (25.4\%), punishing (16.9\%) and cruel (13.5\%). In evaluative category, most common were: troublesome (27.8\%), intense (27.8\%) and miserable (25.9\%). In miscellaneous, most common were: penetrating (20.3\%), tight (13\%) and dreadful (11.6\%).

Number of sub-categories may be evaluated by each group, individually or by total. Table 3 shows maximum number of categories selected by group and total. We decided to evidence maximum score found for each category.

In the ten sensory category subgroups, maximum chosen were 5 subgroups to define pain in $35 \%$ of participants. In the affective category, maximum number was 3 out of 5 subgroups in $45 \%$ of participants. In evaluative, the choice of this group, which is made up of just one subgroup, was unanimous. In miscellaneous, almost all subgroups were selected, or 3 out of 4 , by $60 \%$ of participants.

Pain index is obtained by adding the corresponding score of each selected word in each category. This index may be obtained by each category or by total score. Table 3 shows maximum pain index for each individual category and maximum total score.

In the sensory category, maximum pain index was 13 in $15 \%$ of patients. In the affective category, 5 was maximum pain index, in $25 \%$ of participants. In evaluative, maximum score was obtained (5) in $40 \%$ of participants. In miscellaneous, 10 was maximum index in $15 \%$ of followed up oncohematologic patients. Maximum score was 34, for $15 \%$ of participants.

Analgesia was daily evaluated as from medical prescription and was compared to pain intensity according to VAS. Analgesia prescriptions were compared according to the analgesic ladder proposed by the World Health Organization $(\mathrm{WHO})^{6}$, which has four steps, the last having been more recently included.

It was observed that from 20 followed up patients, 13 had no analgesia according to WHO schedule. All mild pains were medicated with stronger analgesia than necessary to control pain. Moderate pain was the one following the most WHO recommendations. Severe pain was inadequately treated. No invasive treatment was offered for refractory pain.

The only identified adjuvant analgesic was hyoscine, associated to weak opioid. No other adjuvant analgesics were used, such as antidepressants, anticonvulsants and local anesthetics.

There has been prevalence of weak opioids at fixed time or when necessary, regardless of pain being mild, moderate or severe. Another common practice is the use of analgesics as needed, in $45 \%(n=9)$ of followed up patients.

\section{DISCUSSION}

Our study has observed as major causes of pain intestinal infection and mucositis, which may be related to anti-tumor treatment, post-anti cancer chemotherapy. When evaluating major adverse effects after anti-cancer treatment, mucositis is the most frequent acute effect, being a major cause of symptoms such as loss of appetite and gastrointestinal tract infection $^{10}$. Direct involvement by the tumor is the most frequent cause of cancer patients' pain (70\%), however in 17\% of patients pain is related to the anti-tumor treatment itself ${ }^{11}$.

It was observed that $75 \%$ of patients had severe pain (between 8 and 10), similar to Silva et al. ${ }^{12}$, findings, where $63 \%$ of adult cancer patients had moderate pain in the first day of the study.

In EMADOR, with regard to acute pain, most frequent descriptors were deep, intense, unbearable, desperate and blinding. And for chronic pain they were: persistent, unbearable, hurting, anguishing, disastrous and harmful. Other study ${ }^{3}$ has observed that most prevalent words for chronic pain were depressing, persistent, anguishing, disastrous and harmful. For chronic pain only two descriptors were similar (persistent and anguishing). It is observed that chronic pain generates despair in patients due to its persistence.

Narrative review by Sallum, Garcia \& Sanches 5 consolidates that chronic pain is more than a symptom, but rather a persistent disease which does not disappear even with injury healing. Being a constant and prolonged presence, it may be disturbing and provide changes in daily activities, in addition to changes in mood, self-esteem, negative or suicide thoughts, hopeless appreciation of life and changes in family, professional and leisure relationships, justifying pain descriptors found in this study.

In McGill questionnaire, most frequent words found in this study were jumping, troublesome, intense, miserable and 
penetrating. In a study by Costa \& $\mathrm{Chaves}^{7}$ also applying McGill scale to characterize cancer patients' pain, most frequent words were sickening, tiring, sharp, jumping and tender.

Our results by McGill scale categories were compared to a study by Silva et al. ${ }^{14}$ also with cancer patients. In the sensory category most frequent descriptors were jumping, tugging, and throbbing, different from the base study for comparison where most frequent words were throbbing, cramping and tugging, with coincidence only with throbbing.

Differences might be associated to pain site and type of cancer because jumping, pricking and shocks are more prevalent in neuropathic pain. Throbbing pain may be present in headaches, for example. Tugging pain is common in the abdominal region and might have several possible diagnoses depending on location.

In the affective category, most prevalent words have differed between studies, being exhausting, punishing and cruel the most frequent words in our study, differently from those found in the base study for comparison which were troublesome, tiring and miserable. The important thing in this category is to identify pain emotional aspect and how patients feel in face of it.

McGill questionnaire can be used to find pain index by category or general and to have a notion of which category is more common for each patient or to compare general index with maximum possible score and observe whether pain involves several physical, psychological or behavioral aspects. Among categories, the most frequently selected by followed up patients was evaluative in its totality, showing that they have used words to report their pain experience. Sensory and affective categories were, proportionally, seldom chosen, having both low pain indices, showing that patients make little use of sensory and emotional aspects to define their pain. This result was different from the study of Costa $\&$ Chaves $^{7}$ where the highest number of chosen descriptors was in the sensory category and those with highest index were in the affective category.

Our study has compared analgesia offered to patients with verbal pain complaints to that recommended by the WHO. The same comparison was made in the study by Barbosa et al. ${ }^{15}$. Both studies have observed prevalence of not compliance with WHO guidelines. Some factors might be involved, such as: not using pain VAS to quantify this symptom and inadequate scale application; unawareness of analgesic techniques indicated by the WHO. In case of onco-hematologic patients, another limitation was restriction to the use of nonsteroid anti-inflammatory drugs for pain, because it could inhibit a possible fever and mask a signal indicating infection, especially in leucopenia patients.

The use of adjuvant analgesics is still very limited, being anti- spasmodic the most frequently prescribed class ${ }^{15}$. WHO tries to publicize and encourage the use of other adjuvant classes as important for effective pain control, such as antidepressants (amitriptyline), anticonvulsants (phenytoin, phenobarbital) and hypnotics (midazolam).

The practice of analgesia if necessary was also observed, which is not indicated by the WHO. It is recommended that in prescribing analgesics one should know their therapeutic range, that is, the concentration level which is maintained constant to remain in the analgesia zone, because chronic pain requires preventive treatment, so analgesics should be prescribed at regular intervals ${ }^{6}$. The II National Cancer-Related Pain Consensus states that in Brazil $24.5 \%$ to $46.6 \%$ of cancer pain patients have inadequate pain control $^{16}$.

\section{CONCLUSION}

Scales are extremely important for pain measurement and characterization. Nurses should be at the front of their implementation and use in hospital units, especially in cancer units due to the high incidence of this symptom.

\section{REFERENCES}

1. Merskey H, Bogduk DN. A current list with definitions and notes on usage. In: Classification of Chronic Pain. Seattle: IASP Press; 2012. 207-214p.

2. Rabelo ML, Borella ML. Papel do farmacêutico no seguimento farmacoterapêutico para o controle da dor de origem oncológica. Rev Dor. 2013;14(1):58-60.

3. Sousa FA, Pereira LV, Cardoso R, Hortense P. [Multidimensional pain evaluation scale. Rev Lat Am Enfermagem. 2010;18(1):3-10.

4. Teixeira MJ, Siqueira JTT, Alvarez FK. Fisiopatologia da dor/Glossário de Termos para Semiologia da Dor. In: Siqueira, JTT, Teixeira MJ. Organizadores. Dores orofaciais: diagnóstico e tratamento. Sáo Paulo: Artes Médicas; 2012. 61-81p.

5. Sallum, AM, Garcia DM, Sanches M. Dor aguda e crônica: revisấo narrativa da literatura. Acta Paul Enferm. 2012;25(n.spe1):150-4.

6. Academia Nacional de Cuidados Paliativos (ANCP). Manual de cuidados paliativos. Rio de Janeiro: Diagraphic; 2009. 320p.

7. Costa AI, Chaves MD. Dor em pacientes oncológicos sob tratamento quimioterápico. Rev. Dor. 2012;13(1):45-9.

8. Botegga FH, Fontana RT. A dor como quinto sinal vital: utilização da escala de avaliaçáo por enfermeiros de um hospital geral. Texto Contexto Enferm. 2010;19(2):283-90.

9. Pimenta CAM, Mota DDCF, Cruz DALM. Dor e cuidados paliativos. São Paulo: Manole; 2006. 29-44p.

10. Schirmer EM, Ferrari A, Trindade LC. Evolução da mucosite oral após intervenção nutricional em pacientes oncológicos no serviço de cuidados paliativos. Rev Dor. 2012;13(2): 141-6.

11. Carvalho RT, Parson HA. (Organizadores). Manual de cuidados paliativos. $2^{\mathrm{a}}$ ed. Porto Alegre: Sulina; 2012.

12. Silva PB, Trindade LC, Gallucci MC, Schirr RA. Prevalência de desnutrição e dor em pacientes admitidos pelo serviço de triagem em hospital oncológico. Rev Dor. 2013;14(4):263-6.

13. Morete MC, Minson FP. Instrumentos para a avaliação da dor em pacientes oncológicos. Rev Dor. 2010;1(1):74-80.

14. Silva TO, Silva VR, Martinez MR, Gradim CV. Avaliação da dor em pacientes oncológicos. Rev Enferm UERJ. 2011;19(3):359-63.

15. Barbosa JA, Belém LF, Sette IM, Carmo ES, Pereira GJ, Silva Júnior ED. Farmacoterapia adjuvante no tratamento da dor oncológica. RBPS. 2008;21(2):112-20.

16. Wiermann EG, Diz MP, Caponero R, Lages PS, Araujo CZ, Bettega RT, et al. Consenso Brasileiro sobre manejo da dor relacionada ao câncer. Rev Bras Oncol Clín. 2014;10(38):132-43. 